PREPARED FOR THE U.S. DEPARTMENT OF ENERGY, UNDER CONTRACT DE-AC02-76CH03073

PPPL-3995

PPPL-3995

UC-70

\title{
Assessment of ICRF Antenna Performance in Alcator C-Mod
}

by

G. Schilling, S.J. Wukitch, Y. Lin, N. Basse, P.T. Bonoli, E. Edlund, L. Lin, A. Parisot, and M. Porkolab

August 2004
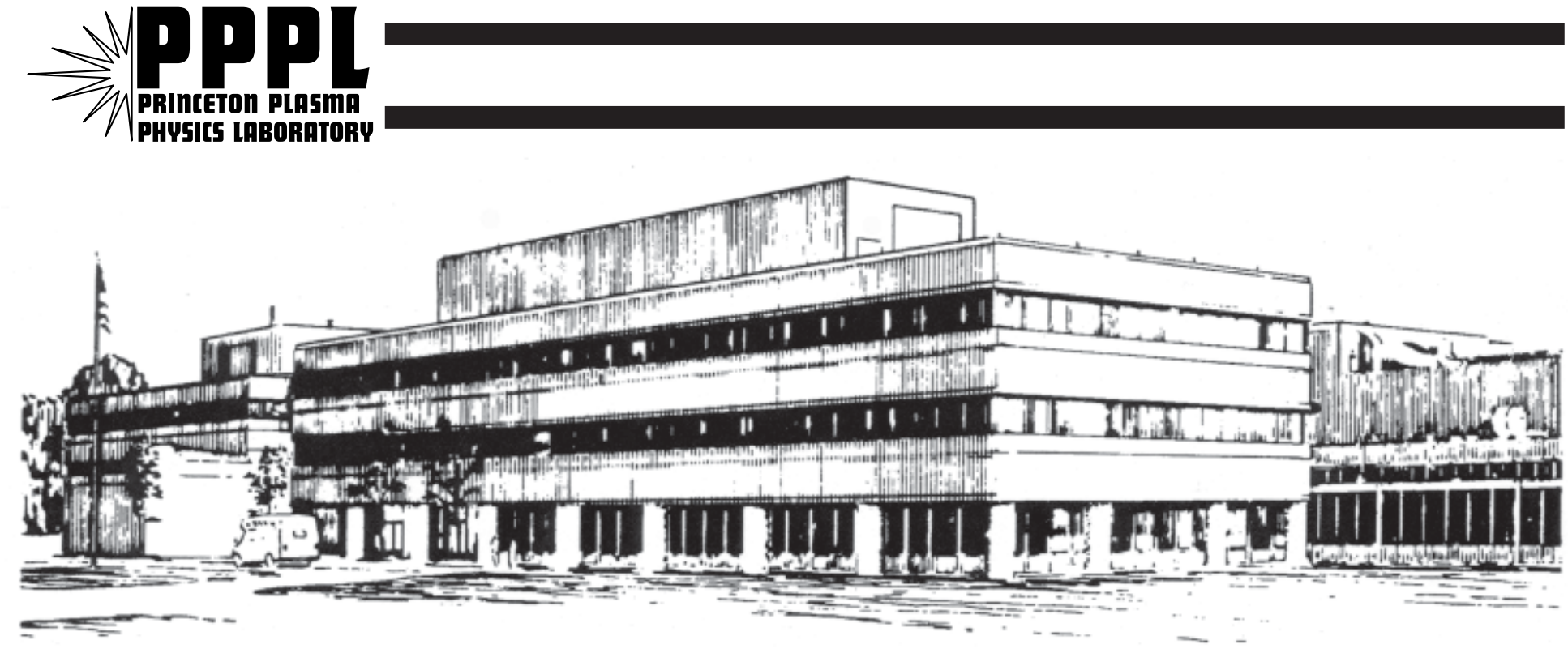

PRINCETON PLASMA PHYSICS LABORATORY PRINCETON UNIVERSITY, PRINCETON, NEW JERSEY 


\section{PPPL Reports Disclaimer}

This report was prepared as an account of work sponsored by an agency of the United States Government. Neither the United States Government nor any agency thereof, nor any of their employees, makes any warranty, express or implied, or assumes any legal liability or responsibility for the accuracy, completeness, or usefulness of any information, apparatus, product, or process disclosed, or represents that its use would not infringe privately owned rights. Reference herein to any specific commercial product, process, or service by trade name, trademark, manufacturer, or otherwise, does not necessarily constitute or imply its endorsement, recommendation, or favoring by the United States Government or any agency thereof. The views and opinions of authors expressed herein do not necessarily state or reflect those of the United States Government or any agency thereof.

\section{Availability}

This report is posted on the U.S. Department of Energy's Princeton Plasma Physics Laboratory Publications and Reports web site in Fiscal Year 2004. The home page for PPPL Reports and Publications is: http://www.pppl.gov/pub_report/

DOE and DOE Contractors can obtain copies of this report from:

U.S. Department of Energy

Office of Scientific and Technical Information

DOE Technical Information Services (DTIS)

P.O. Box 62

Oak Ridge, TN 37831

Telephone: (865) 576-8401

Fax: (865) 576-5728

Email: reports@adonis.osti.gov

This report is available to the general public from:

National Technical Information Service

U.S. Department of Commerce

5285 Port Royal Road

Springfield, VA 22161

Telephone: $1-800-553-6847$ or

(703) $605-6000$

Fax: (703) 321-8547

Internet: http://www.ntis.gov/ordering.htm 


\title{
Assessment of ICRF Antenna Performance in Alcator C-Mod
}

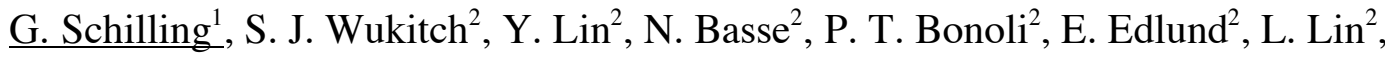 \\ A. Parisot ${ }^{2}$, and M. Porkolab ${ }^{2}$ \\ ${ }^{I}$ Princeton Plasma Physics Laboratory, Princeton, NJ, USA \\ ${ }^{2}$ MIT Plasma Science and Fusion Center, Cambridge, MA, USA
}

\section{ICRF ANTENNA DESCRIPTION}

The Alcator C-Mod ICRF system consists of three antennas: two 2-strap antennas, each connected to a 2-MW transmitter, and one 4-strap antenna, whose current straps are connected in pairs to two 2-MW transmitters. The 4-strap antenna design adds the capability of a directed launched wave spectrum for current drive by changes in current strap phasing. ${ }^{1}$ The antennas exhibit several design differences. ${ }^{2}$ The Faraday shields of the 2-strap antennas are $\sim 27 \%$ transparent and aligned with the net (toroidal plus poloidal) magnetic field, while those of the 4-strap antenna are $~ 50 \%$ transparent and aligned with the toroidal

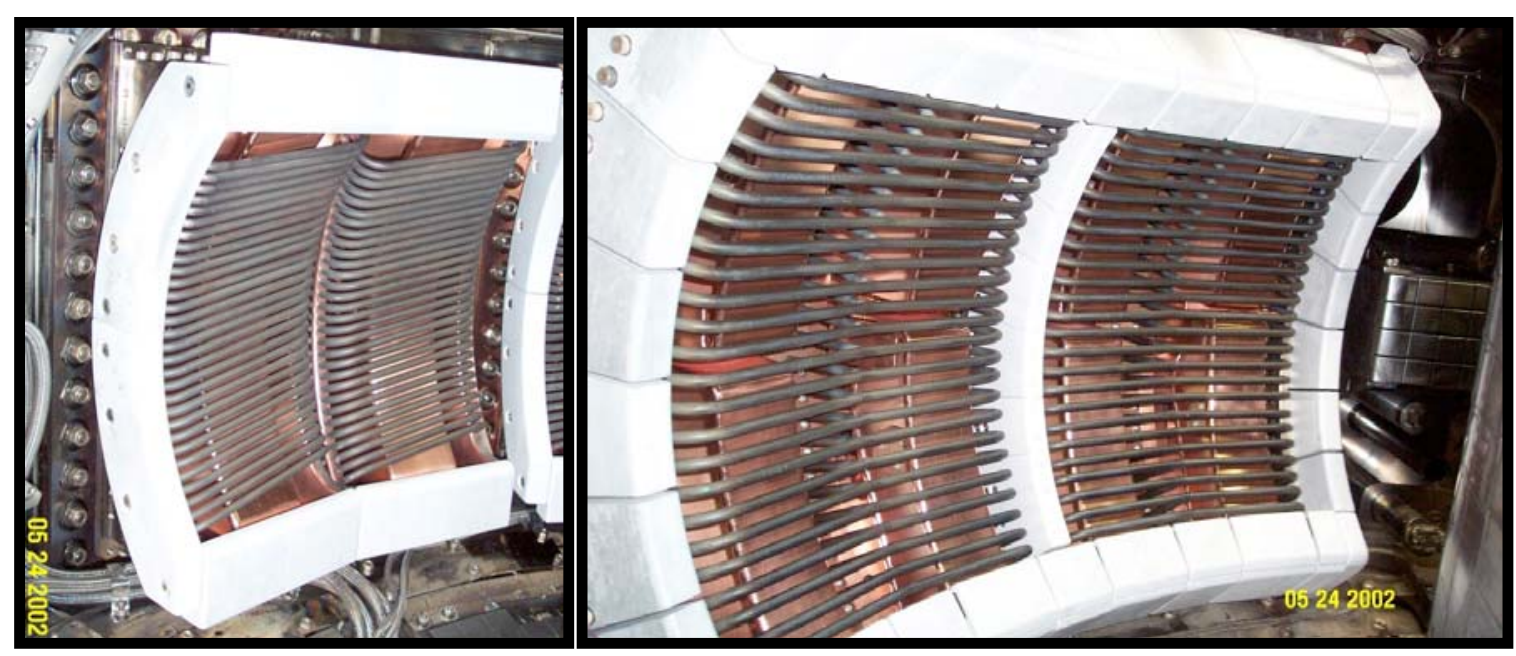

FIGURE 1. One of the two 2-strap antennas (left), and the 4-strap antenna (right).

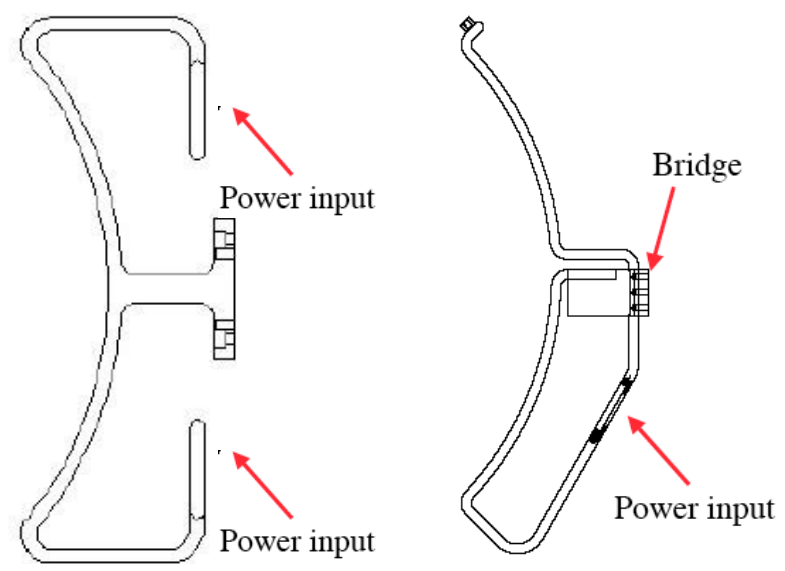

FIGURE 2. Current strap of the 2-strap antenna (left), and the 4-strap antenna (right). magnetic field (Figure 1). Differences exist in the current straps as well. The current straps of the 2-strap antennas are end-fed center-grounded, while those of the 4-strap antenna are folded, end-grounded with a central current feed (Figure 2). The straps exhibit spectral differences as well, $\mathrm{n}_{\varphi}= \pm 10$ vs. $\mathrm{n}_{\varphi}= \pm 13$ for heating phasing. 


\section{ANTENNA PERFORMANCE LIMITATIONS}

The antennas' ability to deliver useful power to the plasma was found to be limited by the injection of impurities into the plasma or by internal arcing at high voltage limits. Both these limits have been pushed upwards through systematic antenna improvements that eliminated impurity generation and improved high voltage handling. ${ }^{3,4}$

Operation with the initial metal plasma-facing components was satisfactory, but the level of Mo impurity in the plasma core was found to scale with the rf power. Although the source rate was low, plasma screening was poor. ${ }^{5}$ The antenna's plasma protection tiles were therefore changed from the original molybdenum to boron nitride to completely shield all metal surfaces, BN-metal interfaces, and eliminate sheath rectification effects. ${ }^{6}$

Extensive arc damage has been observed in the 4-strap antenna between the striplines feeding rf current to the antenna straps, in a direction along the tokamak edge magnetic field. This corresponded to an empirical electric field limit of $\sim 15 \mathrm{kV} / \mathrm{cm}$ under the local conditions, i.e. EllB, and plasma edge neutral gas pressure up to $\sim 1 \mathrm{mTorr}$. The mechanism for this breakdown is not clear. ${ }^{2}$ Field emission initiation requires local field strengths considerably higher than those present. For gas breakdown, the Paschen curve minimum is $\sim$ Torr- $\mathrm{cm}$, while at the antenna we have $\sim$ mTorr-cm, with mean free paths much greater than the electrode spacing. Multipactoring initiation would require lower electric fields or greater path lengths.

The striplines of the 4-strap antenna were redesigned to reorient them to an $\mathbf{E} \perp \mathbf{B}$ configuration (Figure 4) ${ }^{7}$. In order to reduce the electric field below $10 \mathrm{kV} / \mathrm{cm}$ in regions with $\mathbf{E} \| \mathbf{B}$, high voltage gaps were increased, and in the case of arcing at the current strap

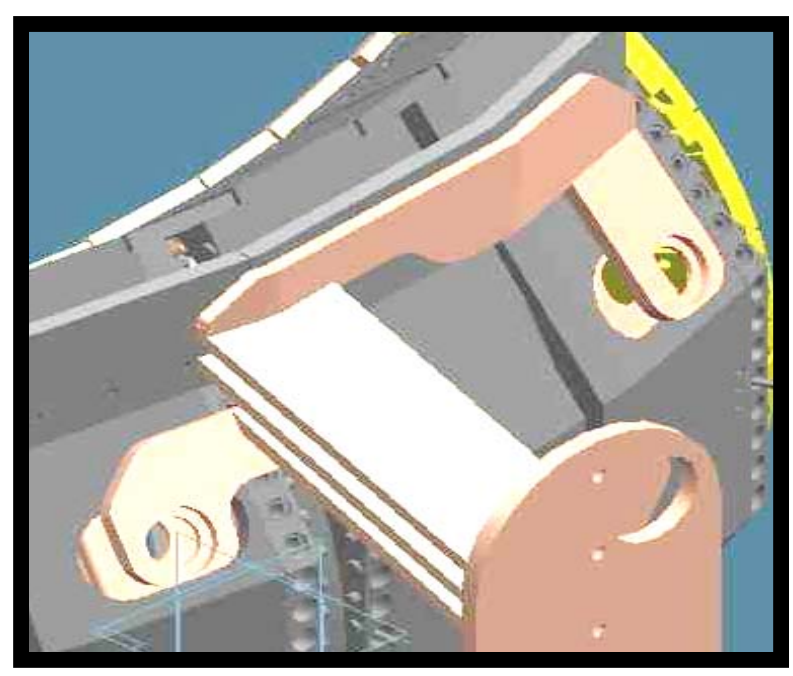

crossover, electrodes were reshaped to reorient the region of highest field.

FIGURE 4. Modified $\mathbf{E} \perp \mathbf{B}$ current feed design.

The tokamak magnetic field rises at $\sim 30^{\circ}$ to the right. 


\section{ANTENNA PERFORMANCE COMPARISON}

The 2-strap and 4-strap antenna performance was compared in two different ways. First, the plasma response to the two different antenna types was compared (Figure 5). In an L-mode discharge 2.7 MW were coupled through the 4-strap antenna at J-port in co-current phasing, followed by the same power through the two 2-strap antennas at D and E-port.

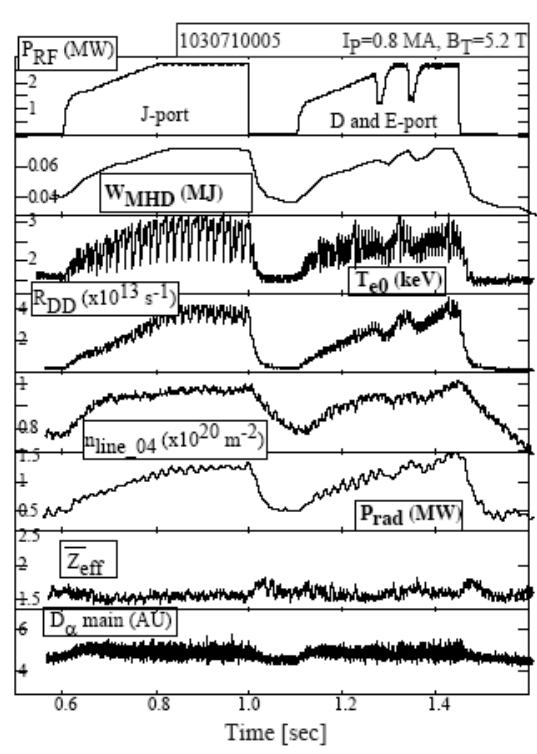

FIGURE 5. Antenna comparison

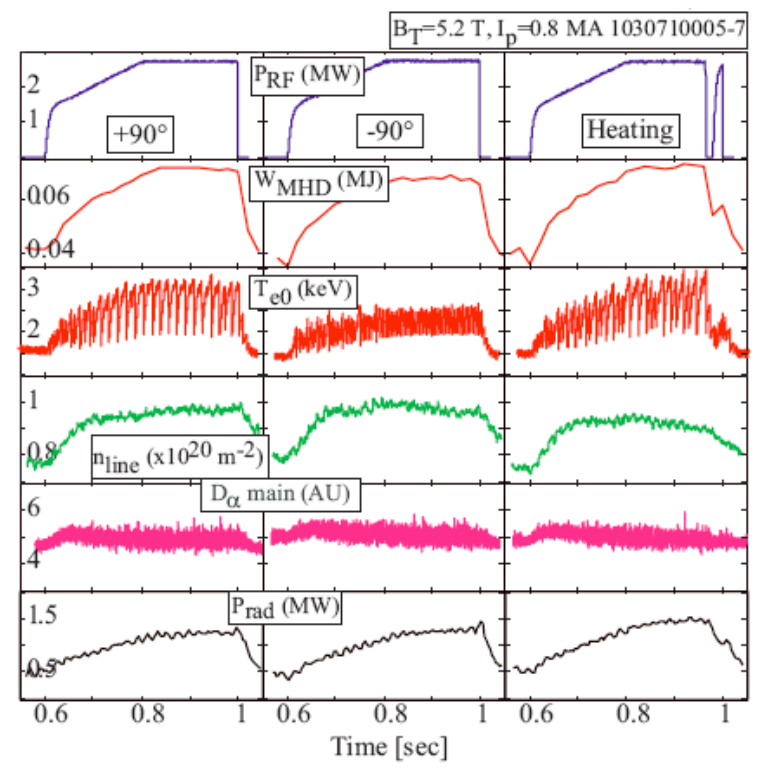

FIGURE 6. 4-strap antenna phasing comparison

The plasma response to the same antenna at different phasings was then compared. A series of limited L-mode discharges was run, and the phasing of the 4-strap antenna was systematically varied while keeping the power constant (Figure 6). In both comparisons all the observed diagnostics, stored energy, electron temperature, neutron rate, density rise, radiated power, $Z_{\text {eff }}$, and $D_{\alpha}$ are the same within $\sim 10 \%$. These comparisons indicate that the differences in antenna construction, Faraday screen transparency and orientation, and current strap design do not result in observable differences in the plasma response.

\section{TECHNICAL ACHIEVEMENTS}

All antennas now are able to be brought up to a peak rf voltage of $35 \mathrm{kV}$ when operating into plasma. The two 2strap antennas achieve power levels of 1.5 MW each, and the 4-strap antenna has achieved $3 \mathrm{MW}$. Total power into plasma has reached $5 \mathrm{MW}$ for 0.6 second (FIGURE 7, right) and 6 MW for $\sim 0.1$ second. On-axis plasma heating power density can exceed $10 \mathrm{MWm}^{-3}$.

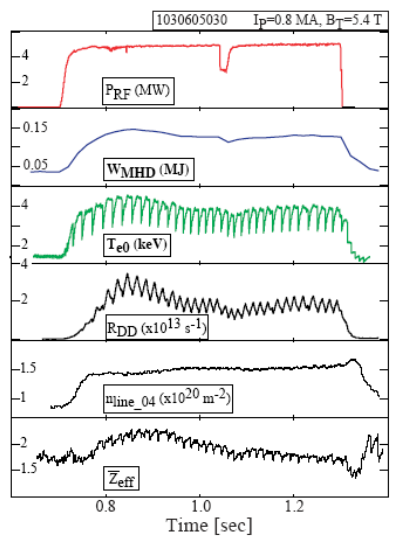




\section{EXPERIMENTAL FLEXIBILITY}

The C-Mod ICRF system now allows an extremely useful and flexible combination of ICRF frequencies, toroidal field setting, and phasing for a variety of physics experiments.

\begin{tabular}{|c|c|c|c|c|c|c|}
\hline $\begin{array}{l}\text { B }_{\text {toroidal }} \\
\text { Tesla }\end{array}$ & $\begin{array}{l}\mathrm{D}+\mathrm{E} \\
\text { frequ. } \\
\mathrm{MHz}\end{array}$ & $\begin{array}{l}\mathrm{J} \\
\text { frequ. } \\
\mathrm{MHz}\end{array}$ & $\begin{array}{l}\mathrm{D}+\mathrm{E} \\
\text { location }\end{array}$ & $\begin{array}{l}\mathrm{J} \\
\text { location }\end{array}$ & $\mathrm{J}$ phasing & Goal \\
\hline 5.4 & $\begin{array}{l}80 \\
80.5\end{array}$ & 78 & $\mathbf{r} / \mathbf{a} \sim 0$ & $\mathrm{r} / \mathrm{a} \sim 0$ & $\begin{array}{l}\text { heating } \\
(0, \pi, 0, \pi)\end{array}$ & $\begin{array}{l}\text { maximum on-axis } \\
\text { heating }\end{array}$ \\
\hline 5.4 & $\begin{array}{l}80 \\
80.5\end{array}$ & 70 & $\mathbf{r} / \mathbf{a} \sim 0$ & $\begin{array}{l}\mathrm{r} / \mathrm{a} \sim \\
+0.5\end{array}$ & $\begin{array}{l}\text { heating } \\
(0, \pi, 0, \pi)\end{array}$ & $\begin{array}{l}\text { off and on-axis } \\
\text { heating for LFS ITB }\end{array}$ \\
\hline 4.5 & $\begin{array}{l}80, \\
80.5\end{array}$ & 70 & $\begin{array}{l}\mathbf{r} / \mathbf{a} \sim \\
-0.5\end{array}$ & $\mathbf{r} / \mathbf{a} \sim 0$ & $\begin{array}{l}\text { heating } \\
(0, \pi, 0, \pi)\end{array}$ & $\begin{array}{l}\text { off and on-axis } \\
\text { heating for HFS ITB }\end{array}$ \\
\hline 5.2 & $\begin{array}{l}80 \\
80.5\end{array}$ & 78 & $\mathbf{r} / \mathbf{a} \sim 0$ & $\mathbf{r} / \mathbf{a} \sim 0$ & $\mathrm{CD}\left( \pm 90^{\circ}\right)$ & $\begin{array}{l}\text { on-axis heating and } \\
\text { current drive }\end{array}$ \\
\hline 8.0 & $\begin{array}{l}80 \\
80.5\end{array}$ & 78 & $\begin{array}{l}\mathbf{r} / \mathbf{a} \sim \\
0-0.2\end{array}$ & $\begin{array}{l}\mathbf{r} / \mathrm{a} \sim \\
0-0.2\end{array}$ & $\mathrm{CD}\left( \pm 90^{\circ}\right)$ & $\begin{array}{l}\text { on/off-axis } \mathrm{D}\left({ }^{3} \mathrm{He}\right) \\
\text { heating and } \mathrm{MCCD}\end{array}$ \\
\hline
\end{tabular}

SUMMARY

C-Mod has presented a challenge to install high power ICRF antennas in a tight space. Modifications have been made to the antenna plasma-facing surfaces and the internal current-carrying structure in order to overcome performance limitations. At the present time the antennas have exceeded $5 \mathrm{MW}$ into plasma with heating phasing, up to $2.7 \mathrm{MW}$ with current drive phasing, with good efficiency and no deleterious effects.

\section{ACKNOWLEDGEMENTS}

Work supported by US DoE Contract DE-AC02-76-CH0-3073 and Cooperative Agreement DE-FC02-99ER54512. Engineering support by W. Beck, P. Koert, C. Schwartz, and R. Vieira, MIT PSFC, and C. Brunkhorst, PPPL, is gratefully appreciated.

\section{REFERENCES}

${ }^{1}$ G. Schilling et al., "Extension of Alcator C-Mod's ICRF Experimental Capability," Proceedings of the $13^{\text {th }}$ Topical Conference on Radio Frequency Power in Plasmas, Annapolis MD, April 1999, 429-432.

${ }^{2}$ S. J. Wukitch et al., "Investigation of Performance Limiting Phenomena in a Variable Phase ICRF Antenna in Alcator C-Mod," submitted to Plasma Physics and Controlled Fusion.

${ }^{3}$ G. Schilling et al., "Upgrades to the 4-strap ICRF Antenna in Alcator C-Mod," Proceedings of the $14^{\text {th }}$ Topical Conference on Radio Frequency Power in Plasmas, Oxnard CA, May 2001, 186-189.

${ }^{4}$ S. J. Wukitch et al., "Performance of a Compact Four-Strap Fast Wave ICRF Antenna," presented at the19th IAEA Fusion Energy Conference, Lyon, France, 14 - 19 October 2002, FT/P1-14.

${ }^{5}$ B. Lipschultz et al., "A Study of Molybdenum Influxes and Transport in Alcator C-Mod," Nuclear Fusion 41, (2001) 585.

${ }^{6}$ J. W. Myra and D. A. D’Ippolito, “Far Field ICRF Sheath Formation on Walls and Limiters," Proceedings of the Tenth Topical Conference on Radio Frequency Power in Plasmas, Boston MA, April 1993, 421-424.

${ }^{7}$ G. Schilling et al., "Analysis of 4-strap ICRF Antenna Performance in Alcator C-Mod," Proceedings of the $15^{\text {th }}$ Topical Conference on Radio Frequency Power in Plasmas, Moran WY, May 2003, 166. 


\section{External Distribution}

Plasma Research Laboratory, Australian National University, Australia

Professor I.R. Jones, Flinders University, Australia

Professor João Canalle, Instituto de Fisica DEQ/IF - UERJ, Brazil

Mr. Gerson O. Ludwig, Instituto Nacional de Pesquisas, Brazil

Dr. P.H. Sakanaka, Instituto Fisica, Brazil

The Librarian, Culham Laboratory, England

Mrs. S.A. Hutchinson, JET Library, England

Professor M.N. Bussac, Ecole Polytechnique, France

Librarian, Max-Planck-Institut für Plasmaphysik, Germany

Jolan Moldvai, Reports Library, Hungarian Academy of Sciences, Central Research Institute for Physics, Hungary

Dr. P. Kaw, Institute for Plasma Research, India

Ms. P.J. Pathak, Librarian, Institute for Plasma Research, India

Ms. Clelia De Palo, Associazione EURATOM-ENEA, Italy

Dr. G. Grosso, Instituto di Fisica del Plasma, Italy

Librarian, Naka Fusion Research Establishment, JAERI, Japan

Library, Laboratory for Complex Energy Processes, Institute for Advanced Study, Kyoto University, Japan

Research Information Center, National Institute for Fusion Science, Japan

Dr. O. Mitarai, Kyushu Tokai University, Japan

Dr. Jiangang Li, Institute of Plasma Physics, Chinese Academy of Sciences, People's Republic of China

Professor Yuping Huo, School of Physical Science and Technology, People's Republic of China

Library, Academia Sinica, Institute of Plasma Physics, People's Republic of China

Librarian, Institute of Physics, Chinese Academy of Sciences, People's Republic of China

Dr. S. Mirnov, TRINITI, Troitsk, Russian Federation, Russia

Dr. V.S. Strelkov, Kurchatov Institute, Russian Federation, Russia

Professor Peter Lukac, Katedra Fyziky Plazmy MFF UK, Mlynska dolina F-2, Komenskeho Univerzita, SK-842 15 Bratislava, Slovakia

Dr. G.S. Lee, Korea Basic Science Institute, South Korea

Institute for Plasma Research, University of Maryland, USA

Librarian, Fusion Energy Division, Oak Ridge National Laboratory, USA

Librarian, Institute of Fusion Studies, University of Texas, USA

Librarian, Magnetic Fusion Program, Lawrence Livermore National Laboratory, USA

Library, General Atomics, USA

Plasma Physics Group, Fusion Energy Research Program, University of California at San Diego, USA

Plasma Physics Library, Columbia University, USA

Alkesh Punjabi, Center for Fusion Research and Training, Hampton University, USA

Dr. W.M. Stacey, Fusion Research Center, Georgia Institute of Technology, USA

Dr. John Willis, U.S. Department of Energy, Office of Fusion Energy Sciences, USA

Mr. Paul H. Wright, Indianapolis, Indiana, USA 
The Princeton Plasma Physics Laboratory is operated by Princeton University under contract with the U.S. Department of Energy.

\author{
Information Services \\ Princeton Plasma Physics Laboratory \\ P.O. Box 451 \\ Princeton, NJ 08543
}

Phone: 609-243-2750

Fax: 609-243-2751

e-mail: pppl_info@pppl.gov

Internet Address: http://www.pppl.gov 